\title{
Crystal Structures of SgcE6 and SgcC, the Two-Component Monooxygenase that Catalyzes Hydroxylation of a Carrier Protein-Tethered Substrate in Biosynthesis of the Enediyne Antitumor Antibiotic C-1027 in Streptomyces globisporus
}

Chin-Yuan Chang, ${ }^{1, \dagger}$ Jeremy R. Lohman, ${ }^{1, \dagger}$ Hongnan Cao, ${ }^{2}$ Kemin Tan, ${ }^{3}$ Jeffrey D. Rudolf, ${ }^{1}$ Ming Ma, ${ }^{1}$ Weijun Xu, ${ }^{2}$ Craig A. Bingman, ${ }^{4}$ Ragothaman M. Yennamalli, ${ }^{2,5}$ Lance Bigelow, ${ }^{3}$ Gyorgy Babnigg, ${ }^{3}$ Xiaohui Yan, ${ }^{1}$ Andrzej Joachimiak, ${ }^{3}$ George N. Phillips, Jr., ${ }^{2}$ and Ben Shen*, ${ }^{1,6,7}$

${ }^{1}$ Department of Chemistry, The Scripps Research Institute, Jupiter, FL 33458, United States;

${ }^{2}$ BioScience at Rice and Department of Chemistry, Rice University, Houston, TX 77251, United States; ${ }^{3}$ Midwest Center for Structural Genomics and Structural Biology Center, Biosciences Division, Argonne National Laboratory, Argonne, IL 60439, United States;

${ }^{4}$ Department of Biochemistry, University Wisconsin-Madison, Madison, WI 53705, United States; ${ }^{5}$ Department of Biotechnology and Bioinfomatics, Jaypee University of Information Technology, Waknaghat, Himachal Pradesh, India 173234, and ${ }^{6}$ Department of Molecular Therapeutics and ${ }^{7}$ Natural Products Library Initiative at The Scripps Research Institute, The Scripps Research Institute, Jupiter, FL 33458, United States

${ }^{\dagger}$ These authors contributed equally

*Correspondence: E-mail: shenb@scripps.edu. Telephone: (561) 228-2456. Fax: (561) 228-2472.

\section{Supporting Information}

Table S1. $\quad$ Primers and vectors used in this study S2

Table S2. Homologues of SgcE6 discussed in this study S3

Table S3. Homologues of SgcC discussed in this study S5

Figure S1. The top ten templates used by I-TASSER for SgcC2 modeling $\quad$ S7

Figure S2. Sequence alignment of SgcE6 with selected homologues S8

Figure S3. Sequence alignment of $\mathrm{SgcC}$ with selected homologues S9

Figure S4. Stereoimage of SgcE6 monomer alignment S10

Figure S5. Structural comparison of SgcE6 with other flavin reductases

Figure S6. Molecular weight estimation of SgcE6 and SgcC S12

Figure S7. Reactions carried out by SgcC homologous enzymes $\quad$ S13

Figure S8. Structure based sequence alignment identity matrix $\quad$ S14

Figure S9. Comparison of SgcC and TtHpaB in stereograms $\quad$ S15

Figure S10. Active site of AbHpaH $\quad$ S16

Figure S11. The SgcC-SgcC2 docking model $\quad$ S17

$\begin{array}{ll}\text { References } & \text { S18 }\end{array}$ 
Table S1. Primers and vectors used in this study.

\begin{tabular}{|c|c|c|}
\hline Plasmid & PCR primers & Cloning vector \\
\hline \multirow{2}{*}{$\begin{array}{l}\text { APC109096 } \\
\text { (pBS1159) }\end{array}$} & SgcE6-F: 5'-TACTTCCAATCCAATGCCATGAGTCCGATCATCGCTCCG-3' & \multirow{2}{*}{ pMCSG73 } \\
\hline & SgcE6-R: 5'-TTATCCACTTCCAATGTTATGCCGCCCTTCCTTCGTCC-3' & \\
\hline \multirow{2}{*}{$\begin{array}{l}\text { APC109081 } \\
(\mathrm{pBS} 1160)\end{array}$} & SgcC-F: 5'-AAAACCTCTATTTCCAGTCGCCCCACGGTGCAGAGCGCG-3' & \multirow{2}{*}{ pBS3080 } \\
\hline & SgcC-R: 5'-TACTTACTTAAATGTTACAGCCCTCCGAGAAGGTCG-3' & \\
\hline
\end{tabular}


Table S2. Homologues of SgcE6 discussed in this study.

\begin{tabular}{|c|c|c|c|c|c|c|c|c|c|c|c|c|c|}
\hline \multirow[t]{2}{*}{ Organism } & \multirow[t]{2}{*}{ Abbreviation } & \multirow{2}{*}{$\begin{array}{l}\text { Substrate } \\
\text { (Fixed } \\
\text { concentration) }\end{array}$} & \multirow{2}{*}{$\begin{array}{l}\text { Second } \\
\text { substrate }\end{array}$} & \multirow[t]{2}{*}{$\kappa_{\mathrm{m}}(\mu \mathrm{M})$} & \multirow[t]{2}{*}{$K_{\text {cat }}\left(\mathbf{s}^{-1}\right)$} & \multicolumn{5}{|c|}{ DALI analysis } & \multirow{2}{*}{$\begin{array}{l}\text { Accession } \\
\text { number }\end{array}$} & \multirow[t]{2}{*}{ PDB ID } & \multirow[t]{2}{*}{ Reference } \\
\hline & & & & & & $\% \mathbf{i d}^{\mathrm{a}}$ & $z^{\mathfrak{b}}$ & $\mathrm{rmsd}^{\mathrm{c}}$ & lali $^{\mathrm{d}}$ & nres $^{e}$ & & & \\
\hline \multirow{4}{*}{$\begin{array}{l}\text { Streptomyces } \\
\text { globisporus }\end{array}$} & \multirow[t]{4}{*}{ SgcE6 } & FAD & $\mathrm{NADH}$ & 8.2 & 4.5 & \multirow[t]{4}{*}{ - } & \multirow[t]{4}{*}{ - } & \multirow[t]{4}{*}{ - } & \multirow[t]{4}{*}{ - } & \multirow[t]{4}{*}{-} & \multirow[t]{4}{*}{ AAL06698 } & \multirow{4}{*}{$\begin{array}{l}4 \mathrm{R} 82, \\
4 \mathrm{HX} 6\end{array}$} & \multirow[t]{4}{*}{1} \\
\hline & & FMN & $\mathrm{NADH}$ & \multicolumn{2}{|c|}{ Very low activity } & & & & & & & & \\
\hline & & $\mathrm{NADH}$ & FAD & 53 & 3.1 & & & & & & & & \\
\hline & & NADPH & FAD & \multicolumn{2}{|c|}{ Below detection } & & & & & & & & \\
\hline \multirow{4}{*}{$\begin{array}{l}\text { Thermus thermophilus } \\
\text { HB8 }\end{array}$} & \multirow[t]{4}{*}{ TtHpaC } & FAD & $\mathrm{NADH}$ & 8.9 & 2.4 & \multirow[t]{4}{*}{33} & \multirow[t]{4}{*}{22.5} & \multirow[t]{4}{*}{1.6} & \multirow[t]{4}{*}{147} & \multirow[t]{4}{*}{149} & \multirow[t]{4}{*}{ BAD70784 } & \multirow{4}{*}{$\begin{array}{l}\text { 2ED4, } \\
2 \mathrm{ECR} \\
2 \mathrm{ECU}\end{array}$} & 2 \\
\hline & & FMN & $\mathrm{NADH}$ & 39.6 & 2.7 & & & & & & & & \\
\hline & & $\mathrm{NADH}$ & FAD & 36.8 & 0.7 & & & & & & & & \\
\hline & & NADPH & FAD & Below de & & & & & & & & & \\
\hline Bacillus & BtPheA2 & FAD & $\mathrm{NADH}$ & 1.5 & 252 & 34 & 24.1 & 1.4 & 149 & 153 & AAF66547 & 1RZ1, & 3,4 \\
\hline A7 & & FMN & $\mathrm{NADH}$ & 5.4 & 279 & & & & & & & & \\
\hline & & $\mathrm{NADH}$ & FAD & 8.8 & 225 & & & & & & & & \\
\hline & & NADPH & FAD & Very low & & & & & & & & & \\
\hline Burkholderia cepacia & $\mathrm{BcTftC}$ & FAD & $\mathrm{NADH}$ & 4.8 & 16.6 & 22 & 22.6 & 1.9 & 156 & 164 & AAC23547 & 3K88, & 5 \\
\hline & & FMN & $\mathrm{NADH}$ & 10.3 & 18.5 & & & & & & & 3K86 & \\
\hline & & $\mathrm{NADH}$ & FAD & 40 & 30.1 & & & & & & & & \\
\hline & & NADPH & FAD & Not perfo & & & & & & & & & \\
\hline Pseudomonas putida & PpSMOB & FAD & $\mathrm{NADH}$ & 11.6 & 47 & 28 & 22.2 & 1.7 & 149 & 152 & AJA17114 & $4 \mathrm{~F} 07$ & 6 \\
\hline (Pseudomonas sp. & & FMN & $\mathrm{NADH}$ & 7.1 & 48 & & & & & & & & \\
\hline & & $\mathrm{NADH}$ & FMN & 20.1 & 60 & & & & & & & & \\
\hline & & NADPH & FMN & Below de & & & & & & & & & \\
\hline $\begin{array}{l}\text { Mycobacterium } \\
\text { thermoresistible }\end{array}$ & MtMOB & No experimental & /idence & & & 32 & 23.2 & 1.9 & 60 & 181 & ADR80228 & $3 N F W$ & 7 \\
\hline
\end{tabular}




\begin{tabular}{|c|c|c|c|c|c|c|c|c|c|c|c|c|c|}
\hline \multirow[t]{3}{*}{ Sulfolobus tokodaii } & \multirow[t]{3}{*}{ StHpaC } & FMN & $\mathrm{NADH}$ & \multicolumn{2}{|c|}{ Relative activity: $100 \%$} & \multirow[t]{3}{*}{24} & \multirow[t]{3}{*}{22.1} & \multirow[t]{3}{*}{1.6} & \multirow[t]{3}{*}{152} & \multirow[t]{3}{*}{155} & \multirow[t]{3}{*}{ BAB65731 } & \multirow{3}{*}{$\begin{array}{l}\text { 2D37, } \\
2 \mathrm{D} 36 \\
2 \mathrm{D} 38\end{array}$} & \multirow[t]{3}{*}{8} \\
\hline & & FMN & NADPH & \multicolumn{2}{|c|}{ Relative activity: $5.4 \%$} & & & & & & & & \\
\hline & & FAD & $\mathrm{NADH}$ & \multicolumn{2}{|c|}{ Relative activity: $67.5 \%$} & & & & & & & & \\
\hline \multirow[t]{4}{*}{ Thermus thermophilus } & \multirow[t]{4}{*}{ TtFMNbp } & NADPH & FMN & $K_{d}=17$ & $\mathrm{~K}_{\mathrm{red}}=0.15$ & \multirow[t]{4}{*}{23} & \multirow[t]{4}{*}{21.0} & \multirow[t]{4}{*}{2.0} & \multirow[t]{4}{*}{161} & \multirow[t]{4}{*}{175} & \multirow[t]{4}{*}{ BAD71681 } & \multirow{4}{*}{$\begin{array}{l}2 \mathrm{ZOE}, \\
1 \mathrm{USC} \\
1 \mathrm{USF}\end{array}$} & \multirow[t]{4}{*}{9} \\
\hline & & $\mathrm{NADH}$ & FMN & $K_{d}=300$ & $\mathrm{~K}_{\mathrm{red}}=0.25$ & & & & & & & & \\
\hline & & NADPH & FAD & \multirow{2}{*}{\multicolumn{2}{|c|}{ No experimental evidence }} & & & & & & & & \\
\hline & & $\mathrm{NADH}$ & FAD & & & & & & & & & & \\
\hline \multirow[t]{4}{*}{ Pyrococcus horikoshii } & \multirow[t]{4}{*}{ PhFMNbp } & NADPH & FMN & $K_{d}=114$ & $\mathrm{~K}_{\mathrm{red}}=0.06$ & \multirow[t]{4}{*}{21} & \multirow[t]{4}{*}{20.4} & \multirow[t]{4}{*}{2.0} & \multirow[t]{4}{*}{156} & \multirow[t]{4}{*}{176} & \multirow[t]{4}{*}{ BAA29950 } & $3 \mathrm{ZOC}$ & 9 \\
\hline & & $\mathrm{NADH}$ & FMN & Below dete & & & & & & & & & \\
\hline & & NADPH & FAD & No experim & al evidence & & & & & & & & \\
\hline & & $\mathrm{NADH}$ & FAD & & & & & & & & & & \\
\hline $\begin{array}{l}\text { Methanobacterium } \\
\text { thermoautotrophicum }\end{array}$ & MtFMNbp & $\begin{array}{l}\text { Structura } \\
\text { No exper }\end{array}$ & $\begin{array}{l}\text { vidence: pro } \\
\text { idence for } 0\end{array}$ & $\begin{array}{l}\text { complex wit } \\
\text { substrates. }\end{array}$ & & 21 & 19.4 & 2.2 & 159 & 192 & AAB84658 & 1EJE & 10 \\
\hline Archaeoglobus & AfFeR & FMN & NADPH & $V_{\max }=280$ & $1 / \mathrm{min} / \mathrm{mg}$ & 25 & 20.4 & 2.6 & 150 & 161 & AAB90418 & $110 \mathrm{~S}$ & 11,12 \\
\hline & & FAD & NADPH & $V_{\max }=350$ & $1 / \mathrm{min} / \mathrm{mg}$ & & & & & & & & \\
\hline & & NADPH & FMN & 0.3 & $\begin{array}{l}\text { Not } \\
\text { performed }\end{array}$ & & & & & & & & \\
\hline & & $\mathrm{NADH}$ & FMN/FAD & Not perforn & & & & & & & & & \\
\hline Escherichia coli W & EcHpaC & FMN & $\mathrm{NADH}$ & 2.1 & $\begin{array}{l}V_{\max }=70 \\
\mu \mathrm{mol} / \mathrm{min} / \mathrm{mg}\end{array}$ & $\begin{array}{l}27 \text { (by } \\
\text { BLAST) }\end{array}$ & & & & & ADT77975 & & 13 \\
\hline & & FAD & $\mathrm{NADH}$ & 3.1 & $\begin{array}{l}V_{\max }=38 \\
\mu \mathrm{mol} / \mathrm{min} / \mathrm{mg}\end{array}$ & & & & & & & & \\
\hline & & $\mathrm{NADH}$ & FMN & 40 & $\begin{array}{l}\text { Not } \\
\text { performed }\end{array}$ & & & & & & & & \\
\hline & & NADPH & FMN & $\begin{array}{l}\text { Not } \\
\text { performed }\end{array}$ & $\begin{array}{l}V_{\max }=0.5 \\
\mu \mathrm{mol} / \mathrm{min} / \mathrm{mg}\end{array}$ & & & & & & & & \\
\hline
\end{tabular}

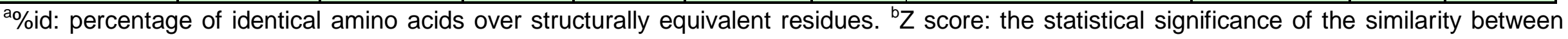
protein-of-interest and other neighbourhood proteins. ${ }^{C} \mathrm{rmsd}$ : root-mean-square deviation of $\mathrm{Ca}$ atoms in the least-squares superimposition of the structurally equivalent $\mathrm{C} \alpha$ atoms. Iali: the number of structurally equivalent residues. ${ }^{e}$ nres: the total number of amino acids in the hit protein. ${ }^{\mathrm{T}}$ The kinetics statistics referred to that of the flavin reductase from Pseudomonas sp. VLB120. The amino acid sequence identity of PpSMOB and the flavin reductase from Pseudomonas sp. VLB120 is $94 \%$. 
Table S3. Homologues of SgcC discussed in this study.

\begin{tabular}{|c|c|c|c|c|c|c|c|c|c|c|c|}
\hline \multirow[t]{2}{*}{ Organism } & \multirow[t]{2}{*}{ Abbreviation } & \multirow[t]{2}{*}{ Flavin } & \multirow[t]{2}{*}{ Function } & \multirow[t]{2}{*}{$\%$ id $^{a}$} & \multicolumn{4}{|c|}{ DALI analysis } & \multirow{2}{*}{$\begin{array}{l}\text { Accession } \\
\text { number }\end{array}$} & \multirow[t]{2}{*}{ PDB ID } & \multirow[t]{2}{*}{ Reference } \\
\hline & & & & & $Z^{\mathfrak{b}}$ & $\mathrm{rmsd}^{\mathrm{c}}$ & Iali $^{\mathrm{d}}$ & nres $^{e}$ & & & \\
\hline $\begin{array}{l}\text { Streptomyces } \\
\text { globisporus }\end{array}$ & $\mathrm{SgcC}$ & FAD & $\begin{array}{l}\text { (S)-3-chloro- } \beta \text {-tyrosyl-S-peptidyl carrier } \\
\text { protein } 5 \text {-hydroxylase }\end{array}$ & - & - & - & - & - & AAL06674 & 4002 & 14 \\
\hline $\begin{array}{l}\text { Thermus thermophilus } \\
\text { HB8 }\end{array}$ & TtHpaB & FAD & 4-hydroxyphenylacetate-3-hydroxylase & 34 & 49.6 & 1.9 & 468 & 470 & BAD70783 & $\begin{array}{l}\text { 2YYJ, 2YYG, 2YYI, } \\
\text { 2YYK, 2YYL, 2YYM }\end{array}$ & 15 \\
\hline $\begin{array}{l}\text { Burkholderia cepacia } \\
\text { AC1100 }\end{array}$ & $\mathrm{BcTftD}$ & FAD & chlorophenol 4-monooxygenase & 26 & 42.7 & 2.3 & 461 & 482 & AAC23548 & $3 \mathrm{HWC}$ & 5 \\
\hline $\begin{array}{l}\text { Cupriavidus necator } \\
\text { JMP134 (Ralstonia } \\
\text { eutropha) }\end{array}$ & CnTcpA & FAD & 2,4,6-trichlorophenol 4-monooxygenase & 22 & 22.6 & 1.9 & 156 & 164 & AAZ60952 & 4G5E & 16 \\
\hline $\begin{array}{l}\text { Pseudomonas } \\
\text { aeruginosa PAO1 }\end{array}$ & PaHpaA & FAD & $\begin{array}{l}\text { 4-hydroxyphenylacetate } \\
\text { 3-monooxygenase }\end{array}$ & 51 & & & & & AAG07478 & & 17,18 \\
\hline Escherichia coli & EcHpaB & FAD & 4-hydroxyphenylacetic hydroxylase & 50 & & & & & ADT77976 & & $19,20,21$ \\
\hline $\begin{array}{l}\text { Bacillus } \\
\text { thermoglucosidasius } \\
\text { A7 (Geobacillus } \\
\text { thermoglucosidasius) }\end{array}$ & BtPheA1 & FAD & phenol 2-hydroxylase & 51 & & & & & AAF66546 & & 22 \\
\hline $\begin{array}{l}\text { Pseudomonas } \\
\text { aeruginosa PAO1 }\end{array}$ & PaPvcC & $\begin{array}{l}\text { No } \\
\text { experimental } \\
\text { evidence }\end{array}$ & $\begin{array}{l}\text { putative hydroxylase (involved in } \\
\text { pyoverdine chromophore biosynthesis) }\end{array}$ & 42 & & & & & AAG05644 & & 23,24 \\
\hline $\begin{array}{l}\text { Geobacillus } \\
\text { thermodenitrificans } \\
\text { NG80-2 }\end{array}$ & $\begin{array}{l}\text { GtHpaH } \\
\text { (GNTG_3160) }\end{array}$ & FAD & putative aromatic compound hydroxylase & 33 & & & & & ABO68505 & & 25 \\
\hline Geobacillus sp. PA-9 & GpHpaH & $\begin{array}{l}\text { No } \\
\text { experimental } \\
\text { evidence }\end{array}$ & $\begin{array}{l}\text { 4-hydroxyphenylacetic acid } \\
\text { 3-hydroxylase }\end{array}$ & 30 & & & & & AAT28189 & & 26 \\
\hline $\begin{array}{l}\text { Rhodococcus opacus } \\
\text { SAO101 (Bacillus } \\
\text { sphaericus JS905) }\end{array}$ & RoNpcA & FAD & 4-nitrophenol 4-monooxygenase & 28 & & & & & BAD30042 & & 27 \\
\hline $\begin{array}{l}\text { Arthrobacter sp. } \\
\text { JS443 }\end{array}$ & AjNpdA2 & FAD & 4-nitrophenol monooxygenase & 28 & & & & & ABL75143 & & 28 \\
\hline $\begin{array}{l}\text { Oscillatoria sp. PCC } \\
6506\end{array}$ & AnaB & FAD & prolyl-ACP dehydrogenase & 10 & 21.5 & 3.2 & 313 & 378 & CBN59192 & $4 \mathrm{IRN}$ & 29 \\
\hline
\end{tabular}




\begin{tabular}{|c|c|c|c|c|c|c|c|c|c|c|c|}
\hline $\begin{array}{l}\text { Streptomyces } \\
\text { hygroscopicus subsp. } \\
\text { ascomyceticus }\end{array}$ & Fkbl & FAD & acyl-ACP dehydrogenase & 16 & 20.4 & 2.9 & 298 & 353 & AAF86388 & 1R2J & 30 \\
\hline $\begin{array}{l}\text { Acinetobacter } \\
\text { baumannii }\end{array}$ & $\mathrm{AbHpaH}$ & FMN & $p$-hydroxyphenylacetate hydroxylase & 7 & 16.2 & 3.5 & 301 & 399 & AAS75429 & 2JBT, 2JBR, 2JBS & 31 \\
\hline Bacillus circulans & BtrO & FMN & $\begin{array}{l}\text { 4-(Y-L-glutamylamino)butanoyl-ACP } \\
\text { monooxygenase }\end{array}$ & & & & & & BAE07076 & & 32 \\
\hline
\end{tabular}

a\%id: amino acid sequence identity. ${ }^{b} Z$ score: the statistical significance of the similarity between protein-of-interest and other neighbourhood proteins. ${ }^{~}$ rmsd: root-mean-square deviation of $\mathrm{C} \alpha$ atoms in the least-squares superimposition of the structurally equivalent $\mathrm{C} \alpha$ atoms. ${ }^{\mathrm{d}}$ lali: the number of structurally equivalent residues. ${ }^{\mathrm{e}}$ nres: the total number of amino acids in the hit protein. 
Figure S1. The top ten threading templates used by I-TASSER for SgcC2 modeling. The residues in template, which are identical to the residue in the query sequence, are highlighted in color. Iden 1 is the sequence identity (\%) of the templates in the threading aligned region with the query sequence. Iden2 is the sequence identity (\%) of the whole template chains with query sequence. Cov represents the coverage of the threading alignment and is equal to the number of aligned residues divided by the length of query protein. Norm. Z-score is the normalized Z-score of the threading alignments.

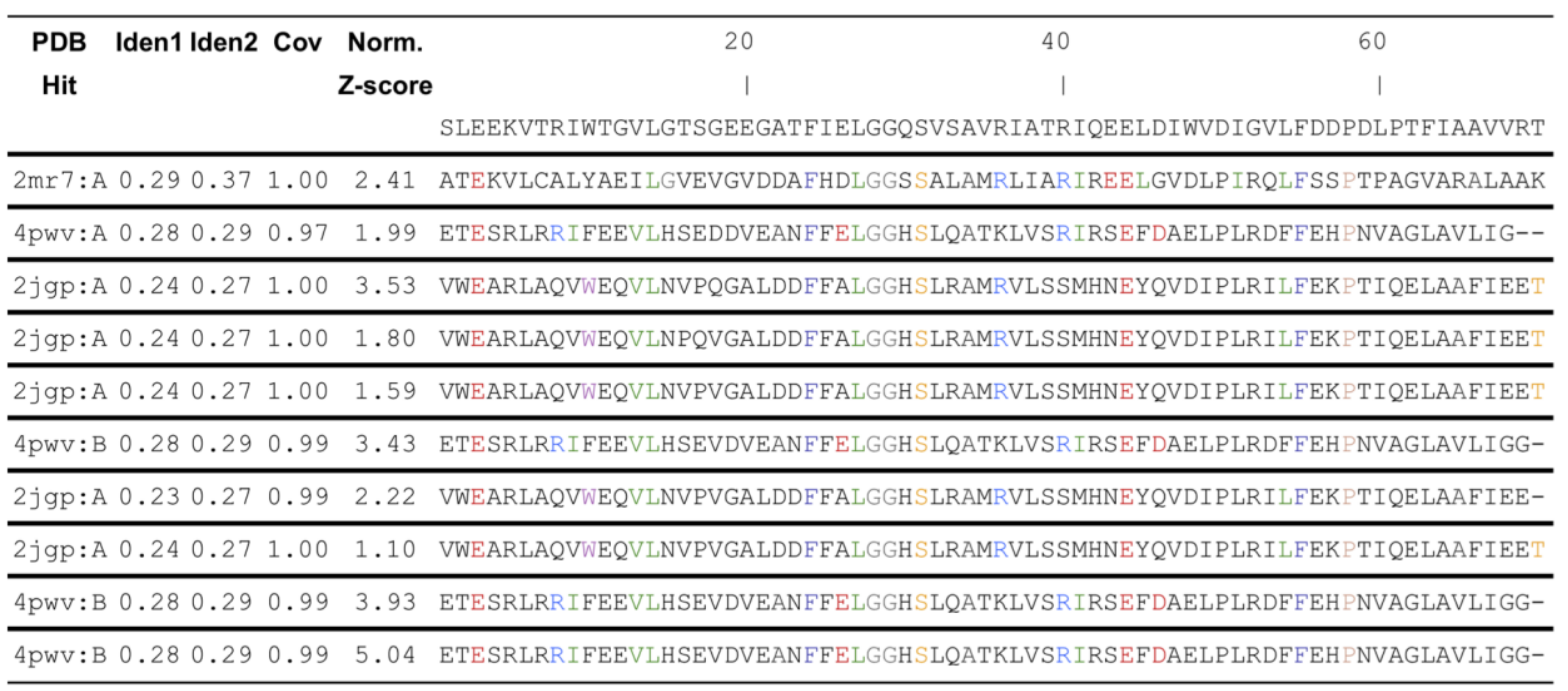


Figure S2. Sequence alignment of SgcE6 with other 9-membered enediyne gene cluster homologues. Accession numbers are shown in front of their sequences. Aligned residues are colored on the basis of the level of conservation (red box with white character or red character with bold font shows strict identity, red character similarity, and blue frame similarity across group). The sequence in red and magenta correlates with either NADH or NADPH preference, the regions in orange and yellow correlate with FMN or FAD preference and the regions in green and cyan highlight the (S/T/C)XXPP and GDH motifs, respectively. The yellow region corresponds to the "flexible AMP binding loop".
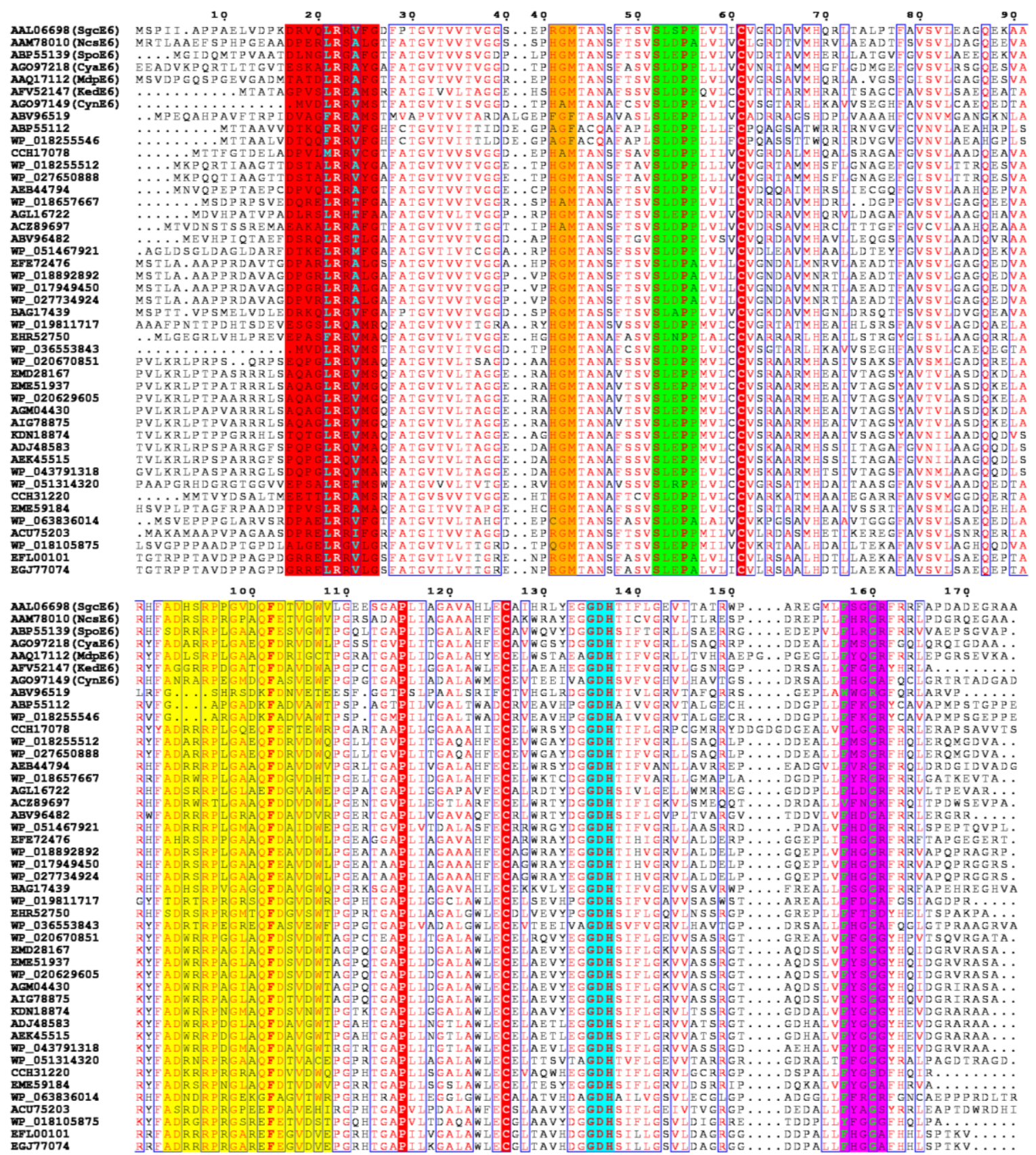
Figure S3. Sequence alignment of $\mathrm{SgcC}$ with other 9-membered enediyne gene cluster homologues. Accession numbers are shown in front of their sequences. Aligned residues are colored on the basis of the level of conservation (red box with white character or red character with bold font shows strict identity, red character similarity, and blue frame similarity across group). The regions in yellow, green and magenta are putative flavin binding loop, substrate binding loop and AMP responsive loop, respectively.

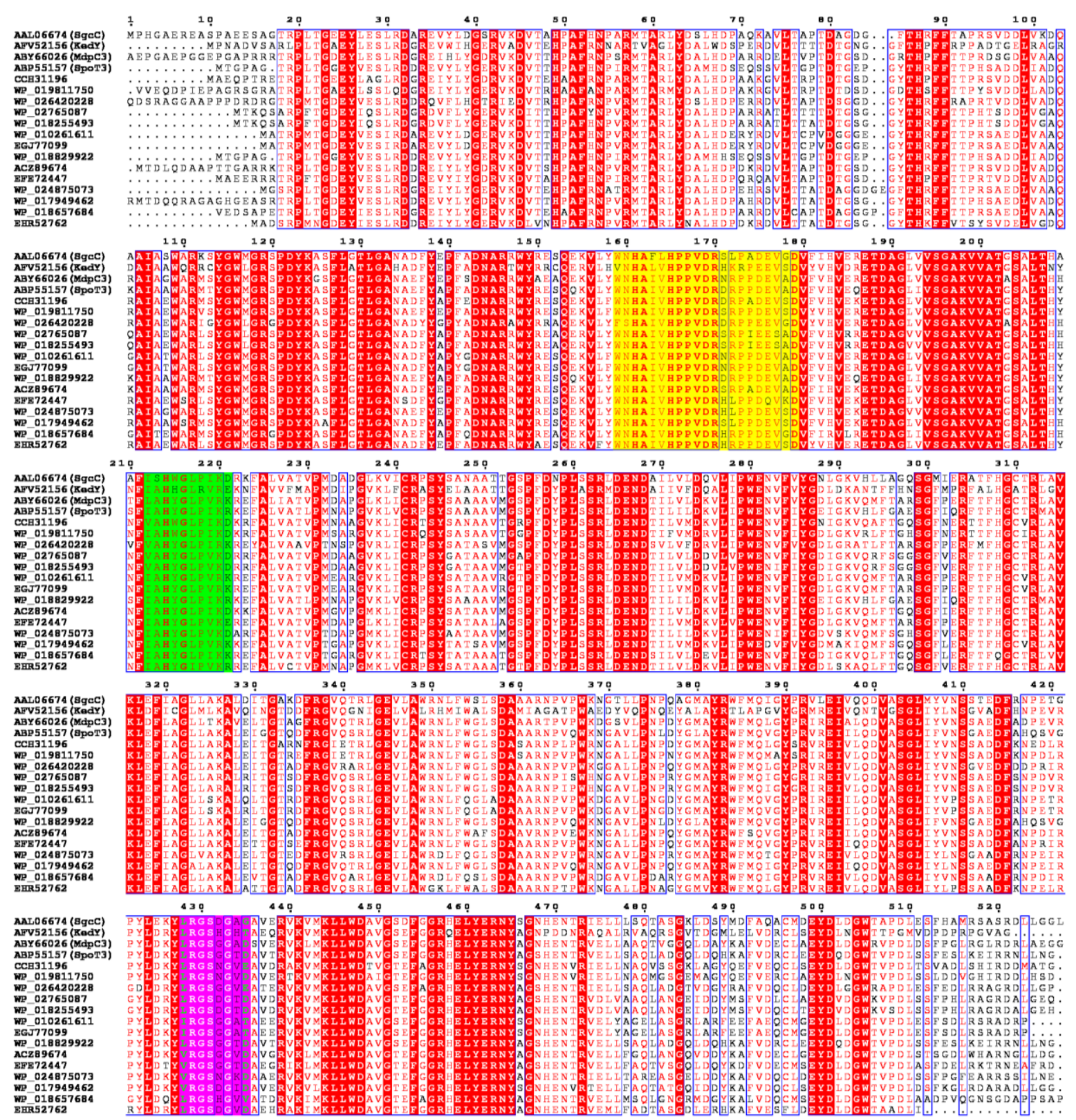


Figure S4. Stereoimage of SgcE6 monomer alignment. The N-terminus, C-terminus and flexible loop are highly variable in position. SgcE6-FAD chain A-black, Apo-SgcE, chain A-green, B-cyan, C-magenta, D-yellow, E-salmon, F-white, G-slate, H-orange.
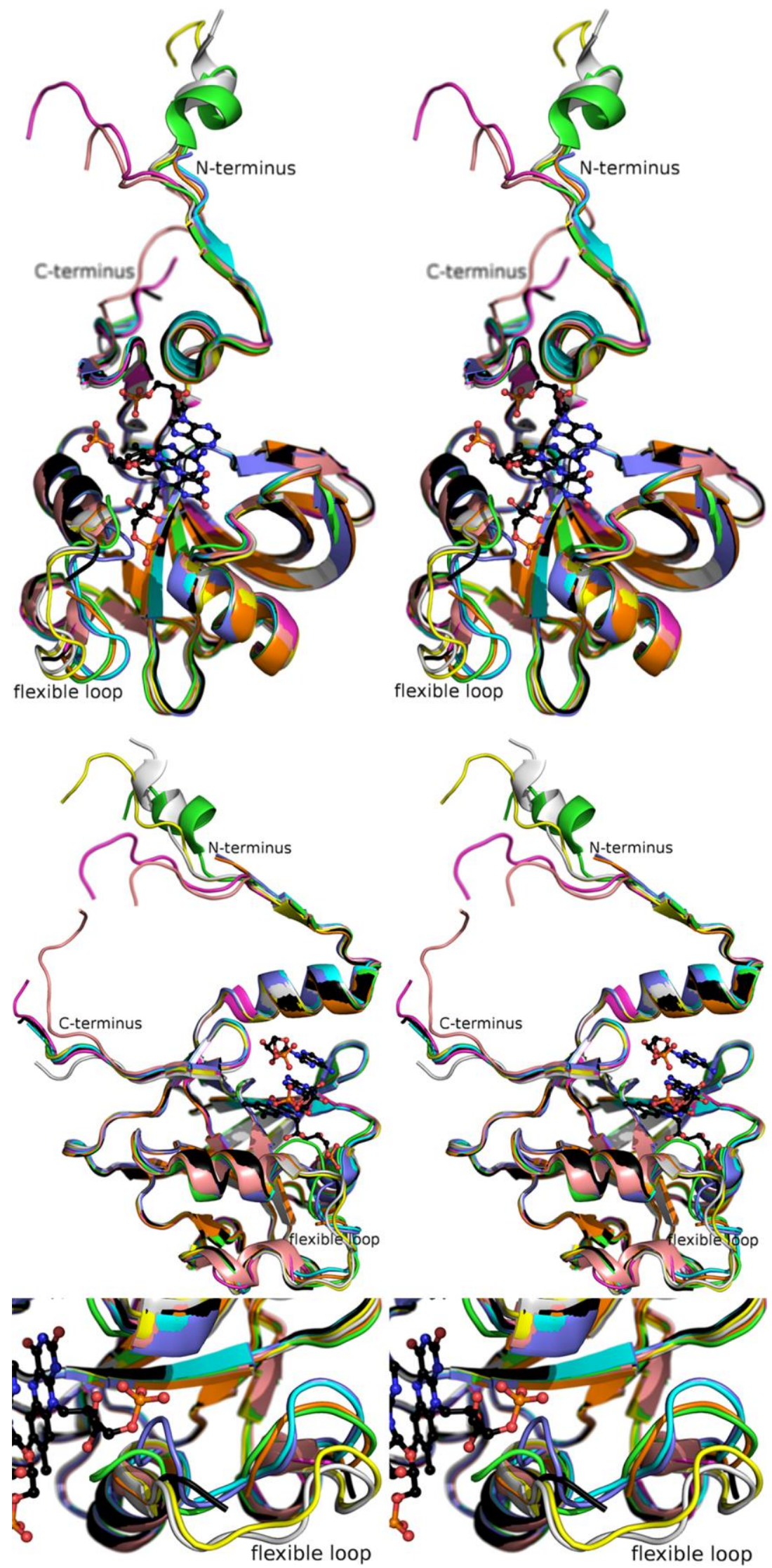
Figure S5. Structural comparison of SgcE6 with other flavin reductases. Colored as seen in Figure 2. The C-terminal loop of MtMOB, which is colored in black, extends into the active site.
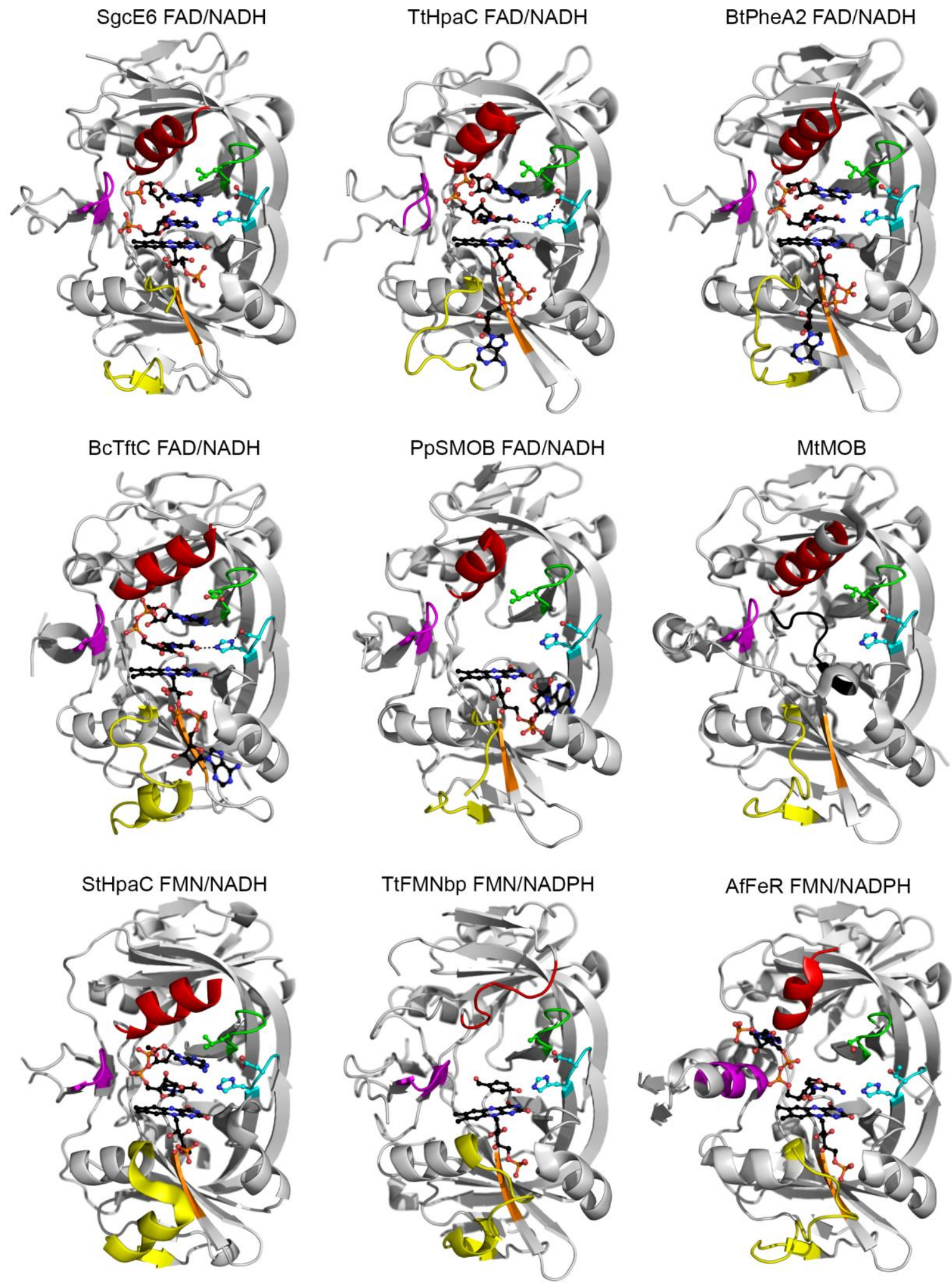
Figure S6. Molecular weight estimation of SgcE6 and SgcC by size exclusion chromatography. (a) SgcE6 and (b) SgcC on a Superdex 200 16/600 column (GE Healthcare Life Science). The apparent molecule weights of SgcE6 and SgcC were estimated to be 46.1 $\mathrm{kDa}$ and $209.7 \mathrm{kDa}$, suggesting that SgcE6 (calculated molecular weight of $19.5 \mathrm{KDa}$ ) and SgcC (calculated molecular weight of $57.9 \mathrm{KDa}$ ) are dimer and tetramer, respectively.

A

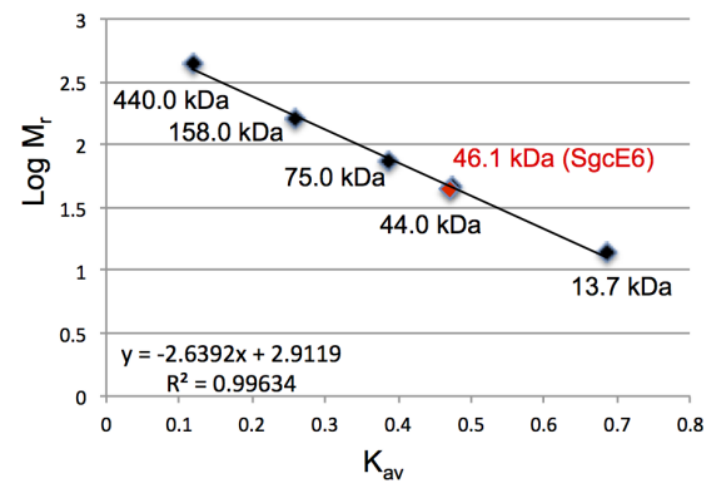

B

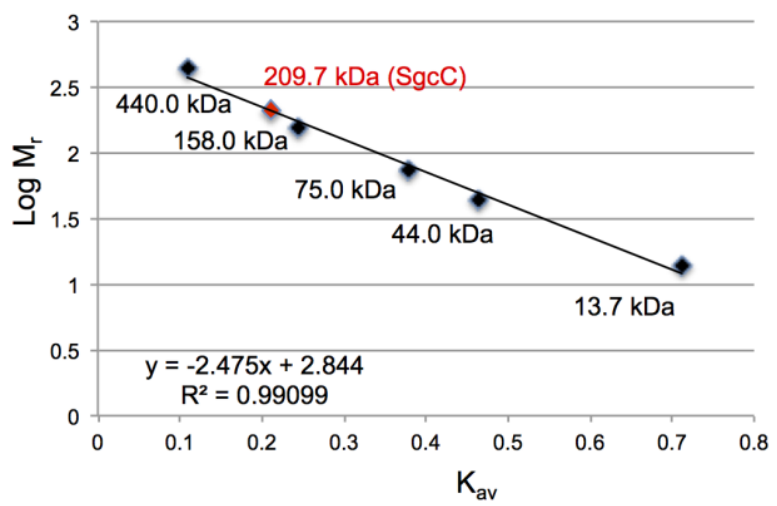


Figure S7. Reactions carried out by SgcC homologous enzymes.

A

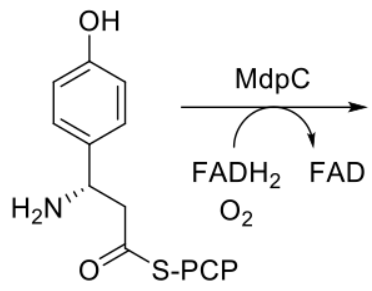

C

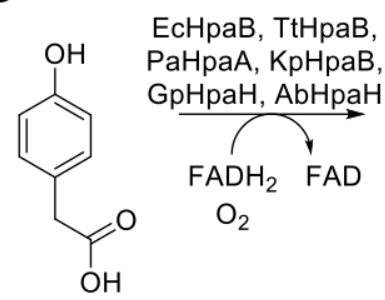

E<smiles>CC(C(=O)O)C(C)C(=O)O</smiles>

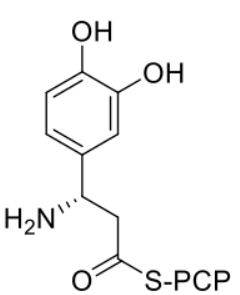

B

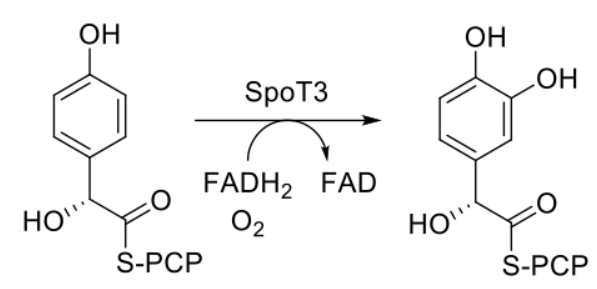

D

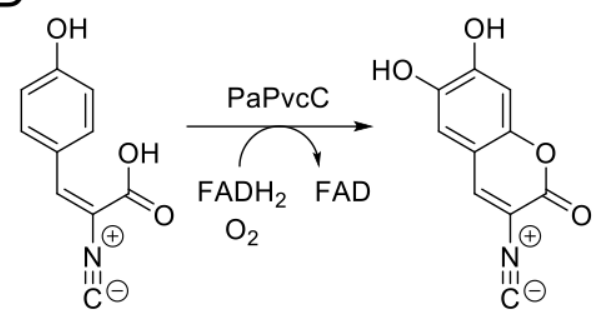

$\mathrm{F}$<smiles>Oc1ccccc1O</smiles><smiles>O=C(O)Cc1ccc(O)c(O)c1</smiles>

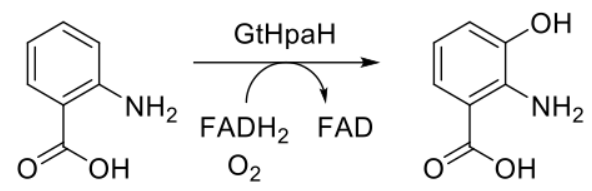

G

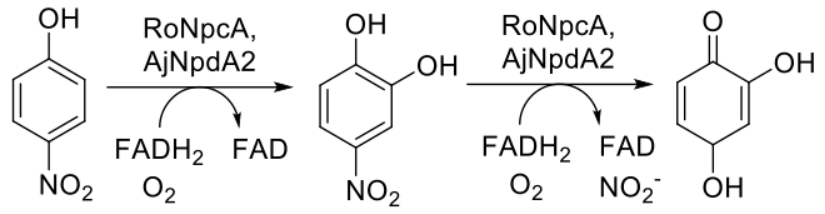

$\mathrm{H}$<smiles>Oc1cc(Cl)c(Cl)cc1Cl</smiles>

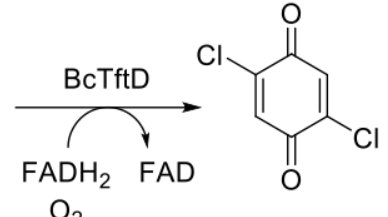<smiles>Oc1cc(Cl)c(Cl)cc1O</smiles>

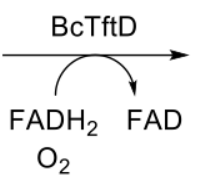<smiles>O=C1C=C(O)C(Cl)=CC1=O</smiles><smiles>Oc1c(Cl)cc(Cl)cc1Cl</smiles>

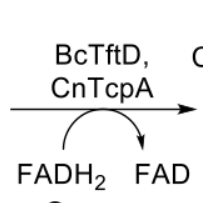<smiles></smiles>

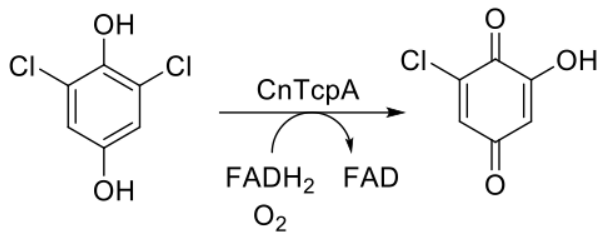


Figure S8. Structure based sequence alignment identity matrix. The sequences for some sequences were left out of Figure 3.

\begin{tabular}{|c|c|c|c|c|c|c|c|c|c|c|c|c|c|c|c|}
\hline & $\begin{array}{l}\text { O } \\
\text { O্口 }\end{array}$ & $\begin{array}{l}\stackrel{m}{\circ} \\
\stackrel{8}{n}\end{array}$ & $\begin{array}{l}\text { O } \\
\text { 음 } \\
\text { L }\end{array}$ & 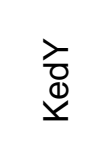 & 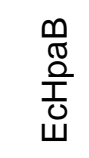 & 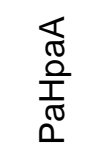 & $\begin{array}{l}0 \\
0 \\
0 \\
0 \\
0 \\
0\end{array}$ & 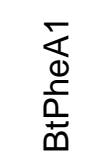 & 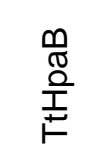 & $\begin{array}{l}\frac{I}{\widetilde{J}} \\
\stackrel{O}{I} \\
\text { I }\end{array}$ & $\begin{array}{l}\frac{T}{\mathbb{N}} \\
\frac{0}{T} \\
\text { 음 }\end{array}$ & 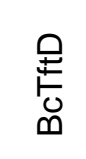 & 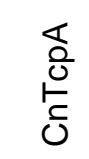 & 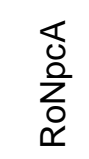 & $\begin{array}{l}\text { 竞 } \\
\text { 遂 }\end{array}$ \\
\hline$g c C$ & 00 & 72 & 0.72 & 0.55 & 0.49 & 0.50 & 0.40 & 0.48 & 0.29 & 0.29 & 0.26 & 0.21 & 0.20 & 0.22 & $0 ?$ \\
\hline SpoT & & 00 & 0.75 & 0.57 & .51 & 0.51 & 0.42 & 0.50 & 0.30 & 0.29 & 0.27 & 0.21 & 0.20 & 0.22 & 0 \\
\hline MdpC & 72 & 0.75 & 1.00 & 0.58 & 0.50 & 0.51 & 0.43 & 0.50 & 0.29 & 0.29 & 0.25 & 0.21 & 0.20 & 0.21 & \\
\hline KedY & 55 & 0.57 & 0.58 & 1.00 & 0.52 & 0.53 & 0.45 & 0.49 & 0.30 & 0.30 & 0.27 & 0.22 & 0.21 & 0.23 & \\
\hline ЕcHpaB & 49 & 0.51 & 0.50 & 0.52 & 1.00 & 0.72 & 0.41 & 0.48 & 0.26 & 0.27 & 0.26 & 0.22 & 0.20 & 0.21 & \\
\hline PaHpaA & 50 & 0.51 & 0.51 & 0.53 & 0.72 & 1.00 & 0.42 & 0.50 & 0.27 & 0.27 & 0.27 & 0.21 & 0.20 & 0.23 & \\
\hline PaPvcC & 40 & 0.42 & 0.43 & 0.45 & 0.41 & 0.42 & 1.00 & 0.44 & 0.27 & 0.31 & 0.25 & 0.20 & 0.20 & 0.22 & \\
\hline BtPheA1 & .48 & 0.50 & 0.50 & 0.49 & 0.48 & 0.50 & 0.44 & 1.00 & 0.29 & 0.29 & 0.29 & 0.23 & 0.22 & 0.24 & \\
\hline TtHpaB & 0.29 & 0.30 & 0.29 & 0.30 & 0.26 & 0.27 & 0.27 & 0.29 & 1.00 & 0.41 & 0.47 & 0.23 & 0.24 & 0.25 & 0.2 \\
\hline GtHpaH & 0.29 & 0.29 & 0.29 & 0.30 & 0.27 & 0.27 & 0.31 & 0.29 & 0.41 & 1.00 & 0.35 & 0.22 & 0.22 & 0.22 & 0.2 \\
\hline GpHpaH & 0.26 & 0.27 & 0.25 & 0.27 & 0.26 & 0.27 & 0.25 & 0.29 & 0.47 & 0.35 & 1.00 & 0.21 & 0.20 & 0.20 & 0.1 \\
\hline BcTftD & 0.21 & 0.21 & 0.21 & 0.22 & 0.22 & 0.21 & 0.20 & 0.23 & 0.23 & 0.22 & 0.21 & 1.00 & 0.65 & 0.43 & \\
\hline CnTcpA & 0.20 & 0.20 & 0.20 & 0.21 & 0.20 & 0.20 & 0.20 & 0.22 & 0.24 & 0.22 & 0.20 & 0.65 & 1.00 & 0.43 & 0.43 \\
\hline RoNpcA & 0.22 & 0.22 & 0.21 & 0.23 & 0.21 & 0.23 & 0.22 & 0.24 & 0.25 & 0.22 & 0.20 & 0.43 & 0.43 & 1.00 & 0.71 \\
\hline AjNpdA2 & 0.21 & 0.22 & 0.21 & 0.22 & 0.21 & 0.20 & 0.21 & 0.22 & 0.23 & 0.20 & 0.19 & 0.41 & 0.43 & 0.71 & 1.00 \\
\hline
\end{tabular}


Figure S9. Comparison of $\mathrm{SgcC}$ and $\mathrm{TtHpaB}$ in stereograms. Colors correspond to sequence alignment in Figure 3. (A) Apo TtHpaB is in white and bright colors, SgcC is in gray and dark colors. (B) Apo TtHpaB is similar to panel A, FAD bound TtHpaB is in gray and dark colors. (C) FAD/4-HPA bound TtHpaB is in white and bright colors and FAD bound TtHpaB is similar to panel $B$. The conformation of the active site loops of TtHpaB changes upon FAD and 4-HPA binding. The conformations seen in SgcC are similar to those of apo TtHpaB.
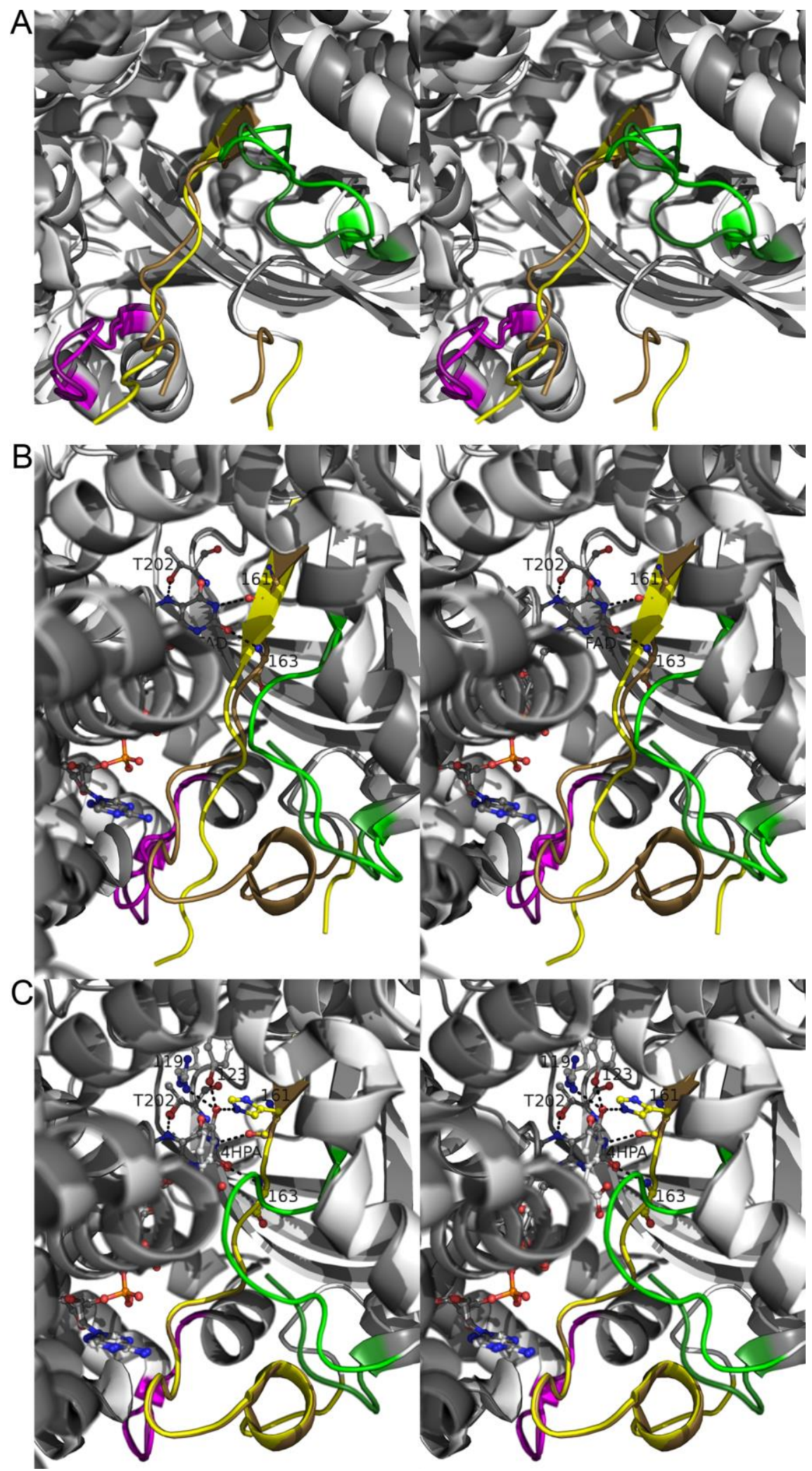
Figure S10. Active site of $\mathrm{AbHpaH}$. The residues are colored similarly to Figure $4 \mathrm{C}$, as the structures of acyl-CoA dehydrogenases and $\mathrm{AbHpaH}$ are very similar. The backbone atoms and $S 171$ bind the flavin ring similarly to those of TtHpaB, revealing a conserved flavin binding mode when compared to Figure 5B. The residues bonding to the phenol of 4HPA in TtHpaB/SgcC differ from AbHpaH, nevertheless the C3 carbons of 4HPA in both AbHpaH and TtHpaB are approximately 5 angstroms from the $\mathrm{C} 4 \mathrm{a}$ of the flavin. This reveals that resides $\mathrm{H} 120$ and $\mathrm{S} 146$ of $\mathrm{AbHpaH}$ serve similar roles as $\mathrm{Y} 123$ and $\mathrm{H} 161$ of $\mathrm{SgcC} / \mathrm{TtHpaB}$. The residue $\mathrm{H} 396$ of $\mathrm{AbHpaH}$ likely fulfils the role of $\mathrm{R} 119$ of $\mathrm{SgcC} / \mathrm{TtHpaB}$, which is likely to form and stabilize the C4a-hydroperoxyflavin intermediate.

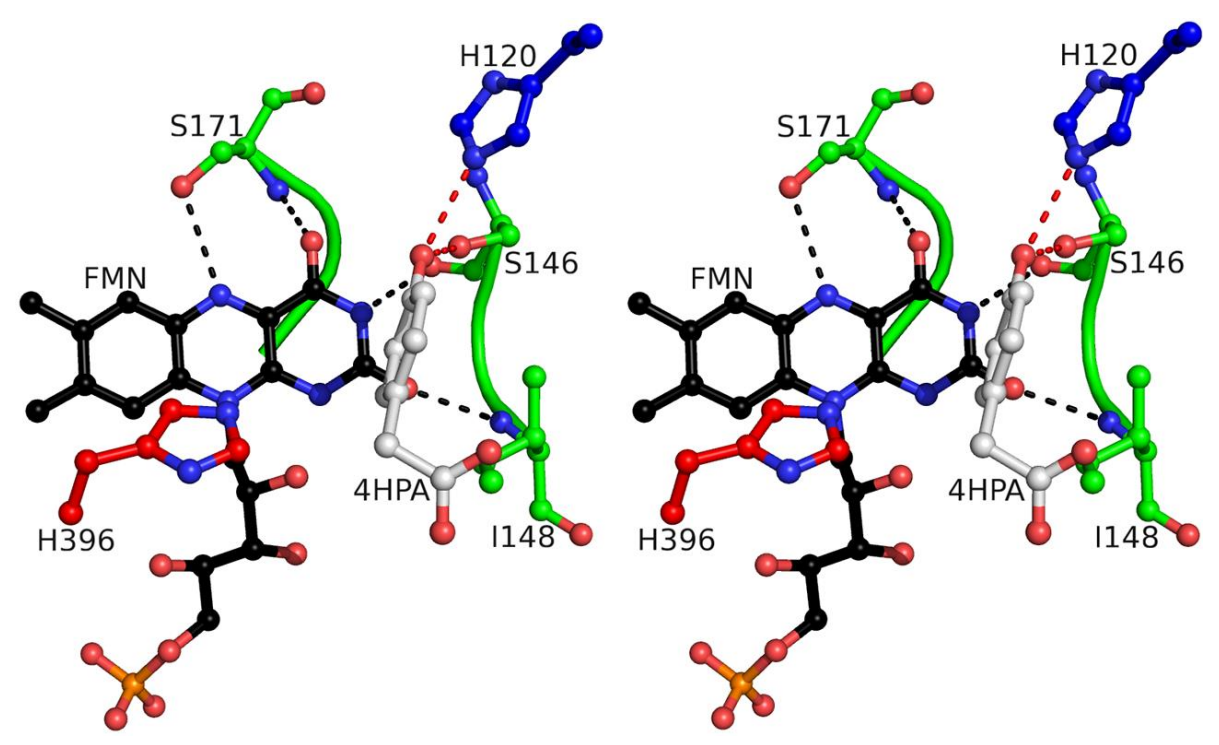


Figure S11. The SgcC-SgcC2 docking model. (a) The functional residues Ser31 (phosphopantetheine-anchored residue, shown in magenta) of SgcC2 points toward the active center of SgcC. (b) SgcC2 is bound at the center of the SgcC tetramer. The four subunits of SgcC are shown in green, cyan, yellow, and blue, respectively, and SgcC2 is shown in gray. The active center of SgcC is shown by red dotted circle. (c) The analysis statistics of the interactions between the SgcC tetramer and SgcC2.

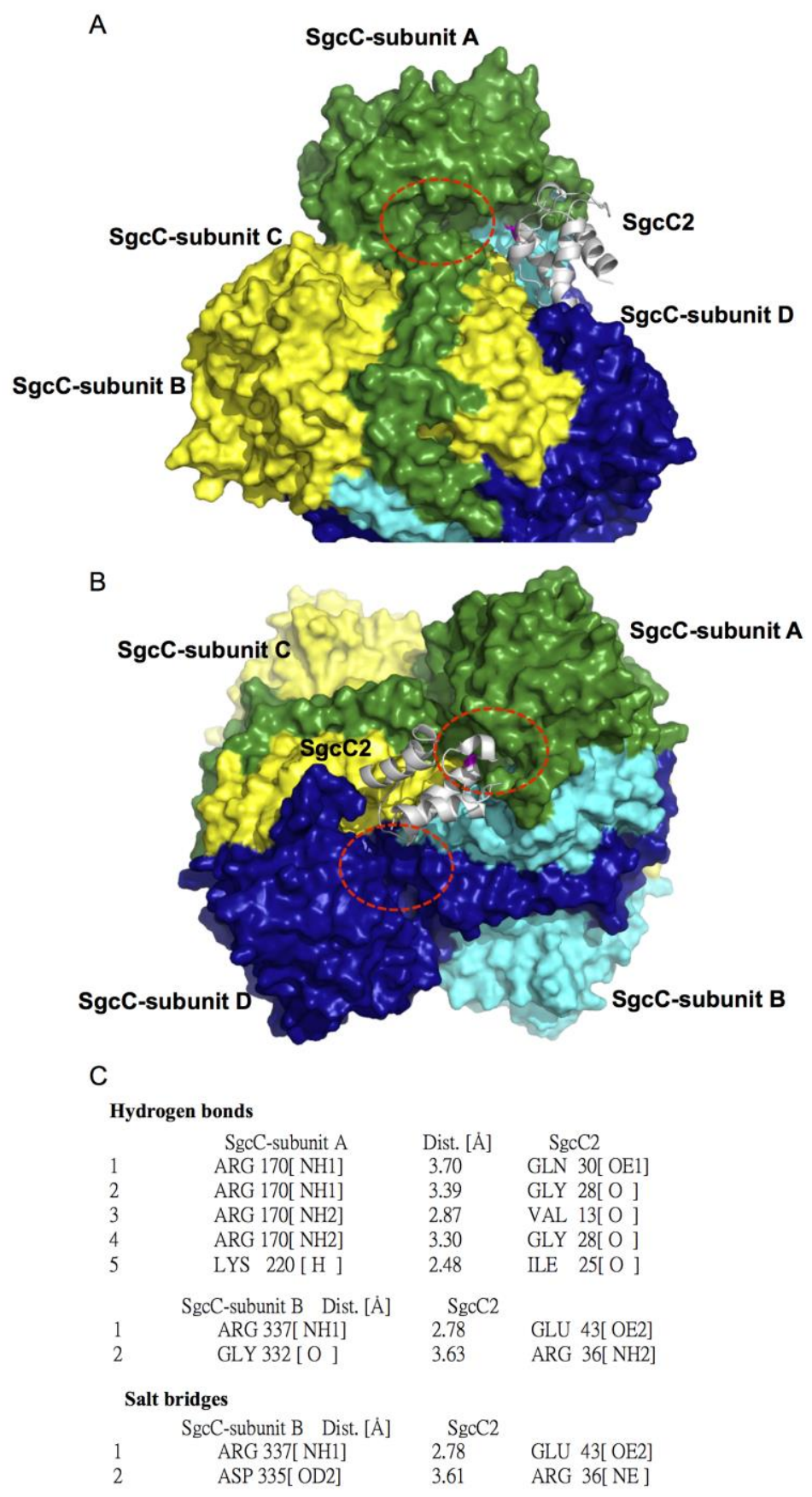




\section{References}

(1) Van Lanen, S. G., Lin, S., Horsman, G. P., and Shen, B. (2009) Characterization of SgcE6, the flavin reductase component supporting FAD-dependent halogenation and hydroxylation in the biosynthesis of the enediyne antitumor antibiotic C-1027. FEMS Microbiol. Lett. 300, 237-241.

(2) Kim, S. H., Hisano, T., Iwasaki, W., Ebihara, A., and Miki, K. (2008) Crystal structure of the flavin reductase component $(\mathrm{HpaC})$ of 4-hydroxyphenylacetate 3-monooxygenase from Thermus thermophilus HB8: Structural basis for the flavin affinity. Proteins 70 , 718-730.

(3) Kirchner, U., Westphal, A. H., Muller, R., and van Berkel, W. J. (2003) Phenol hydroxylase from Bacillus thermoglucosidasius A7, a two-protein component monooxygenase with a dual role for FAD. J. Biol. Chem. 278, 47545-47553.

(4) van den Heuvel, R. H., Westphal, A. H., Heck, A. J., Walsh, M. A., Rovida, S., van Berkel, W. J., and Mattevi, A. (2004) Structural studies on flavin reductase PheA2 reveal binding of NAD in an unusual folded conformation and support novel mechanism of action. J. Biol. Chem. 279, 12860-12867.

(5) Webb, B. N., Ballinger, J. W., Kim, E., Belchik, S. M., Lam, K. S., Youn, B., Nissen, M. S., Xun, L., and Kang, C. (2010) Characterization of chlorophenol 4-monooxygenase (TftD) and NADH:FAD oxidoreductase (TftC) of Burkholderia cepacia AC1100. J. Biol. Chem. 285, 2014-2027.

(6) Otto, K., Hofstetter, K., Rothlisberger, M., Witholt, B., and Schmid, A. (2004) Biochemical characterization of StyAB from Pseudomonas sp. strain VLB120 as a two-component flavin-diffusible monooxygenase. J. Bacteriol. 186, 5292-5302.

(7) Zhang, Y., Edwards, T. E., Begley, D. W., Abramov, A., Thompkins, K. B., Ferrell, M., Guo, W. J., Phan, I., Olsen, C., Napuli, A., Sankaran, B., Stacy, R., Van Voorhis, W. C., Stewart, L. J., and Myler, P. J. (2011) Structure of nitrilotriacetate monooxygenase component B from Mycobacterium thermoresistibile. Acta Cryst. F67, 1100-1105.

(8) Okai, M., Kudo, N., Lee, W. C., Kamo, M., Nagata, K., and Tanokura, M. (2006) Crystal structures of the short-chain flavin reductase HpaC from Sulfolobus tokodaii strain 7 in its three states: $\operatorname{NAD}(\mathrm{P})(+)(-)$ free, $\operatorname{NAD}(+)(-)$ bound, and $\mathrm{NADP}(+)(-)$ bound. Biochemistry 45, 5103-5110.

(9) Steinkellner, G., Gruber, C. C., Pavkov-Keller, T., Binter, A., Steiner, K., Winkler, C., Lyskowski, A., Schwamberger, O., Oberer, M., Schwab, H., Faber, K., Macheroux, P., and Gruber, K. (2014) Identification of promiscuous ene-reductase activity by mining structural databases using active site constellations. Nat. Commun. 5, 4150.

(10) Christendat, D., Yee, A., Dharamsi, A., Kluger, Y., Savchenko, A., Cort, J. R., Booth, V., Mackereth, C. D., Saridakis, V., Ekiel, I., Kozlov, G., Maxwell, K. L., Wu, N., McIntosh, L. P., Gehring, K., Kennedy, M. A., Davidson, A. R., Pai, E. F., Gerstein, M., Edwards, A. M., and Arrowsmith, C. H. (2000) Structural proteomics of an archaeon. Nat. Struct. Biol. 7, 903-909.

(11) Chiu, H. J., Johnson, E., Schroder, I., and Rees, D. C. (2001) Crystal structures of a novel ferric reductase from the hyperthermophilic archaeon Archaeoglobus fulgidus and its complex with NADP+. Structure 9, 311-319.

(12) Vadas, A., Monbouquette, H. G., Johnson, E., and Schroder, I. (1999) Identification and characterization of a novel ferric reductase from the hyperthermophilic Archaeon Archaeoglobus fulgidus. J. Biol. Chem. 274, 36715-36721.

(13) Galan, B., Diaz, E., Prieto, M. A., and Garcia, J. L. (2000) Functional analysis of the small component of the 4-hydroxyphenylacetate 3-monooxygenase of Escherichia coli 
W: a prototype of a new Flavin:NAD $(\mathrm{P}) \mathrm{H}$ reductase subfamily. J. Bacteriol. 182, 627-636.

(14) Lin, S., Van Lanen, S. G., and Shen, B. (2008) Characterization of the two-component, FAD-dependent monooxygenase $\mathrm{SgcC}$ that requires carrier protein-tethered substrates for the biosynthesis of the enediyne antitumor antibiotic C-1027. J. Am. Chem. Soc. 130, 6616-6623.

(15) Kim, S. H., Hisano, T., Takeda, K., Iwasaki, W., Ebihara, A., and Miki, K. (2007) Crystal structure of the oxygenase component (HpaB) of the 4-hydroxyphenylacetate 3-monooxygenase from Thermus thermophilus HB8. J. Biol. Chem. 282, 33107-33117.

(16) Hayes, R. P., Webb, B. N., Subramanian, A. K., Nissen, M., Popchock, A., Xun, L., and Kang, C. (2012) Structural and Catalytic Differences between Two FADH(2)-Dependent Monooxygenases: 2,4,5-TCP 4-Monooxygenase (TftD) from Burkholderia cepacia AC1100 and 2,4,6-TCP 4-Monooxygenase (TcpA) from Cupriavidus necator JMP134. Int. J. Mol. Sci. 13, 9769-9784.

(17) Chakraborty, S., Ortiz-Maldonado, M., Entsch, B., and Ballou, D. P. (2010) Studies on the mechanism of p-hydroxyphenylacetate 3-hydroxylase from Pseudomonas aeruginosa: a system composed of a small flavin reductase and a large flavin-dependent oxygenase. Biochemistry 49, 372-385.

(18) Furuya, T., and Kino, K. (2014) Catalytic activity of the two-component flavin-dependent monooxygenase from Pseudomonas aeruginosa toward cinnamic acid derivatives. Appl. Microbiol. Biotechnol. 98, 1145-1154.

(19) Prieto, M. A., Diaz, E., and Garcia, J. L. (1996) Molecular characterization of the 4-hydroxyphenylacetate catabolic pathway of Escherichia coli W: engineering a mobile aromatic degradative cluster. J. Bacteriol. 178, 111-120.

(20) Xun, L., and Sandvik, E. R. (2000) Characterization of 4-hydroxyphenylacetate 3-hydroxylase (HpaB) of Escherichia coli as a reduced flavin adenine dinucleotide-utilizing monooxygenase. Appl. Environ. Microbiol. 66, 481-486.

(21) Prieto, M. A., and Garcia, J. L. (1994) Molecular characterization of 4-hydroxyphenylacetate 3-hydroxylase of Escherichia coli. A two-protein component enzyme. J. Biol. Chem. 269, 22823-22829.

(22) Duffner, F. M., Kirchner, U., Bauer, M. P., and Muller, R. (2000) Phenol/cresol degradation by the thermophilic Bacillus thermoglucosidasius A7: cloning and sequence analysis of five genes involved in the pathway. Gene 256, 215-221.

(23) Stintzi, A., Johnson, Z., Stonehouse, M., Ochsner, U., Meyer, J. M., Vasil, M. L., and Poole, K. (1999) The pvc gene cluster of Pseudomonas aeruginosa: role in synthesis of the pyoverdine chromophore and regulation by PtxR and PvdS. J. Bacteriol. 181, 4118-4124.

(24) Clarke-Pearson, M. F., and Brady, S. F. (2008) Paerucumarin, a new metabolite produced by the pvc gene cluster from Pseudomonas aeruginosa. J. Bacteriol. 190, 6927-6930.

(25) Liu, X., Dong, Y., Li, X., Ren, Y., Li, Y., Wang, W., Wang, L., and Feng, L. (2010) Characterization of the anthranilate degradation pathway in Geobacillus thermodenitrificans NG80-2. Microbiology 156, 589-595.

(26) Hawumba, J. F., Brozel, V. S., and Theron, J. (2007) Cloning and characterization of a 4-hydroxyphenylacetate 3-hydroxylase from the thermophile Geobacillus sp. PA-9. Curr. Microbiol. 55, 480-484.

(27) Kadiyala, V., and Spain, J. C. (1998) A two-component monooxygenase catalyzes both the hydroxylation of $\mathrm{p}$-nitrophenol and the oxidative release of nitrite from 4-nitrocatechol in Bacillus sphaericus JS905. Appl. Environ. Microbiol. 64, 2479-2484. 
(28) Perry, L. L., and Zylstra, G. J. (2007) Cloning of a gene cluster involved in the catabolism of p-nitrophenol by Arthrobacter sp. strain JS443 and characterization of the p-nitrophenol monooxygenase. J. Bacteriol. 189, 7563-7572.

(29) Moncoq, K., Regad, L., Mann, S., Mejean, A., and Ploux, O. (2013) Structure of the prolyl-acyl carrier protein oxidase involved in the biosynthesis of the cyanotoxin anatoxin-a. Acta Cryst. D69, 2340-2352.

(30) Watanabe, K., Khosla, C., Stroud, R. M., and Tsai, S. C. (2003) Crystal structure of an Acyl-ACP dehydrogenase from the FK520 polyketide biosynthetic pathway: insights into extender unit biosynthesis. J. Mol. Biol. 334, 435-444.

(31) Alfieri, A., Fersini, F., Ruangchan, N., Prongjit, M., Chaiyen, P., and Mattevi, A. (2007) Structure of the monooxygenase component of a two-component flavoprotein monooxygenase. Proc. Natl. Acad. Sci. USA 104, 1177-1182.

(32) Li, Y., Llewellyn, N. M., Giri, R., Huang, F., and Spencer, J. B. (2005) Biosynthesis of the unique amino acid side chain of butirosin: possible protective-group chemistry in an acyl carrier protein-mediated pathway. Chem. Biol. 12, 665-675. 